\title{
New record and phylogenetic affinities of the oomycete Olpidiopsis feldmanni infecting Asparagopsis sp. (Rhodophyta)
}

\author{
Kyle Fletcher ${ }^{1,2}$, Ante Žuljević ${ }^{3}$, Amerssa Tsirigotii ${ }^{4}$, Boris Antolić ${ }^{3}$, \\ Christos Katsaros ${ }^{4}$, Vedran Nikolić ${ }^{3}$, Pieter van West ${ }^{2}$, Frithjof C. Küpper ${ }^{1, *}$ \\ ${ }^{1}$ Oceanlab, University of Aberdeen, Newburgh, AB41 6AA, UK \\ ${ }^{2}$ Aberdeen Oomycete Laboratory, University of Aberdeen, Foresterhill, Aberdeen, AB25 2ZD, UK \\ ${ }^{3}$ Laboratory for Benthos, Institute of Oceanography and Fisheries, Šet. I, Meštrovića 63, HR-21000 Split, Croatia \\ ${ }^{4}$ Department of Botany, Faculty of Biology, University of Athens, Panepistimiopolis, Athens 157 84, Greece
}

\begin{abstract}
A new geographic record of the oomycete Olpidiopsis feldmanni infecting the tetrasporophytic stage of the red alga Asparagopsis sp. from the Adriatic Sea, confirmed through morphological identification, allowed us to expand previous observations of this organism. Ultrastructural investigations of environmental material showed a large central vacuole and a cell wall thicker than previously reported from other basal oomycete pathogens of algae. Phylogenetic analysis closely associates $O$. feldmanni to $O$. bostrychiae concurrent with structural observations. This constitutes the first genetic characterisation of an Olpidiopsis species that was initially described before 1960, adding to the genetic data of 3 other marine Olpidiopsis species established and genetically characterised in the last 2 decades. The paper discusses concurrences of the ultrastructural observations made here and in previous studies of the marine Olpidiopsis species with those made on the freshwater species.
\end{abstract}

KEY WORDS: Central vacuole - Cyochrome oxidase subunit II · COII · cox2 - SSU rRNA · Falkenbergia $\cdot$ Transmission electron microscopy $\cdot$ TEM $\cdot$ Adriatic Sea

\section{INTRODUCTION}

Much remains unknown about the eukaryotic pathogens which infect marine algae (Andrews 1976, Gachon et al. 2010). Studying the majority of these organisms can be difficult due to their often biotrophic nature, meaning that establishing and maintaining pathosystems, consisting of the host and a single pathogen, may not be possible. The eastern Mediterranean has recently been the focus of an investigation into pathogens of brown algae, specifically those of Ectocarpus sp. and Sphacelariales (Strittmatter et al. 2013), although previously only one protistan pathogen affecting algae, viz. Pleotra-

\footnotetext{
*Corresponding author: fkuepper@abdn.ac.uk
}

chelus ectocarpii Jokl, has been described from the Adriatic Sea (Jokl 1916).

While the basal oomycete Eurychasma dicksonii has received the most research interest in recent years (Küpper \& Müller 1999, Küpper et al. 2006, Sekimoto et al. 2008a, Gachon et al. 2009, Tsirigoti et al. 2014, 2015), 3 novel species of Olpidiopsis, i.e. O. bostrychiae Sekimoto, Klochkova, West, Beakes \& Honda (West et al. 2006, Sekimoto et al. 2009), O. porphyrae Sekimoto, Yokoo, Kawamuara \& Honda (Sekimoto et al. 2008b) and O. pyropia Kim \& Klochkova (Klochkova et al. 2015), have recently been described as pathogens of red algae (Table 1). These species are regarded as the most intensively

() The authors 2015. Open Access under Creative Commons by Attribution Licence. Use, distribution and reproduction are unrestricted. Authors and original publication must be credited. 
Table 1. Previously described marine Olpidiopsis sp. and host species from which they were described, listed by year of first description

\begin{tabular}{|c|c|c|}
\hline Species and authority & Year first described & Reported host species \\
\hline $\begin{array}{l}\text { Olpidiopsis andreei } \\
\text { (Lagerheim) Sparrow }\end{array}$ & 1899 & $\begin{array}{l}\text { Spongomorpha sp. } \\
\text { Acrosiphonia sp. } \\
\text { Ectocarpus sp. } \\
\text { Striaria attenuata } \\
\text { Ceramium diaphanum }\end{array}$ \\
\hline $\begin{array}{l}\text { Olpidiopsis feldmanni } \\
\text { Aleem }\end{array}$ & 1952 & $\begin{array}{l}\text { Asparagopsis sp. } \\
\text { tetrasporophytes } \\
\text { Bonnemaisonia hamifera }\end{array}$ \\
\hline $\begin{array}{l}\text { Olpidiopsis magnusii } \\
\text { Feldmann \& Feldmann }\end{array}$ & 1955 & Ceramium flabelligerum \\
\hline $\begin{array}{l}\text { Olpidiopsis dangeardii } \\
\text { Feldmann \& Feldmann }\end{array}$ & 1967 & Radicilingua reptans \\
\hline $\begin{array}{l}\text { Olpidiopsis antithamnionis } \\
\text { Whittick \& South }\end{array}$ & 1972 & Antithamnion floccosum \\
\hline Olpidiopsis bostrychiae & 2006 & Bostrychia sp. \\
\hline $\begin{array}{l}\text { Sekimoto, Klochkova, } \\
\text { West, Beakes \& Honda }\end{array}$ & $\begin{array}{l}\text { (formally des- } \\
\text { cribed 2009) }\end{array}$ & $\begin{array}{l}\text { Stictosiphonia intricata } \\
\text { Porphyra sp. conchocelis } \\
\text { Heterosiphonia japonica }\end{array}$ \\
\hline $\begin{array}{l}\text { Olpidiopsis porphyrae } \\
\text { Sekimoto, Yokoo, } \\
\text { Kawamura \& Honda }\end{array}$ & 2008 & $\begin{array}{l}\text { Pyropia sp. blades } \\
\text { Bangia sp. }\end{array}$ \\
\hline $\begin{array}{l}\text { Olpidiopsis pyropiae } \\
\text { Kim \& Klochkova }\end{array}$ & 2015 & Pyropia sp. \\
\hline
\end{tabular}

O. feldmanni based on morphological observations by light microscopy and was further examined by transmission electron microscopy (TEM). Additionally, we provide the first set of molecular markers for $O$. feldmanni and explore the phylogeny of this organism.

\section{MATERIALS AND METHODS}

\section{Sample collection}

Asparagopsis sp. tetrasporophyte (synonym Falkenbergia) samples were observed during routine phycological examinations of material collected in Kaštela Bay and Vira (Adriatic Sea, Croatia), at irregular intervals between December 2012 and March 2014 (Fig. 1). Samples of Asparagopsis sp. collected from Kaštela Bay were maintained in the aquaria of the Institute of Oceanography and Fisheries (IOF), Croatia, with a constant flow of fresh seawater. The conditions in the tank naturally replicated those of the studied within the genus, having been investigated through molecular and ultrastructural analysis. Comparatively, these 3 marine species appear relatively diverse, with several morphological differences including the flagellation pattern of the zoospores and the presence/absence of a central vacuole (Sekimoto et al. 2008b, 2009, Klochkova et al. 2015). In comparison to other marine members of this genus, O. bostrychiae was noted as being morphologically similar to the little reported O. feldmanni Aleem, 1952, although there was no common reported host between these 2 species (Table 1; West et al. 2006, Sekimoto et al. 2009). Additionally, 4 other marine Olpidiopsis species have been described, though like $O$. feldmanni, they remain to be genetically surveyed (Table 1). The holotype of this genus is O. saprolegniae (Braun) Cornu, 1872, a freshwater pathogen of Saprolegnia (Oomycota) species. As with the marine Olpidiopsis species, freshwater Olpidiopsis species have been studied at the ultrastructural level (Bortnick et al. 1985, Martin \& Miller 1986a,b), but to date, no freshwater Olpidiopsis species have been molecularly surveyed.

The present study aims to characterise a eukaryotic pathogen found on the tetrasporophytic stage of Asparagopsis sp. The pathogen was identified as ambient water of Kaštela Bay due to the positioning of the IOF. Average surface seawater temperature in Kaštela Bay during the survey of Asparagopsis sp. in $2012 / 2013$ was between $17^{\circ} \mathrm{C}$ in November and $11.5^{\circ} \mathrm{C}$ in February (Table 2). Salinity is slightly lower compared to average salinity in the Adriatic Sea due to influence of the River Jadro, dropping from 37.0 PSU in December to 35.5 PSU in March.

Infected filaments containing pathogenic structures were isolated and stained with acetocarmine, to preferentially highlight oomycete structures; permanent microscope mounts were created using Karo ${ }^{\mathrm{TM}}$ syrup (Küpper \& Müller 1999, Strittmatter et al. 2013). Parallel to this, samples were also placed in CTAB buffer for downstream molecular work (Phillips et al. 2001). Studying the micro-photographic database at the IOF allowed the investigation of previous collections to indicate previous occurrences of the infection.

\section{Microscopy}

Live samples and permanent mounts were imaged and processed at the IOF using an Olympus BX51 ${ }^{\mathrm{TM}}$ microscope with a DP12 or Canon 550D camera. Per- 

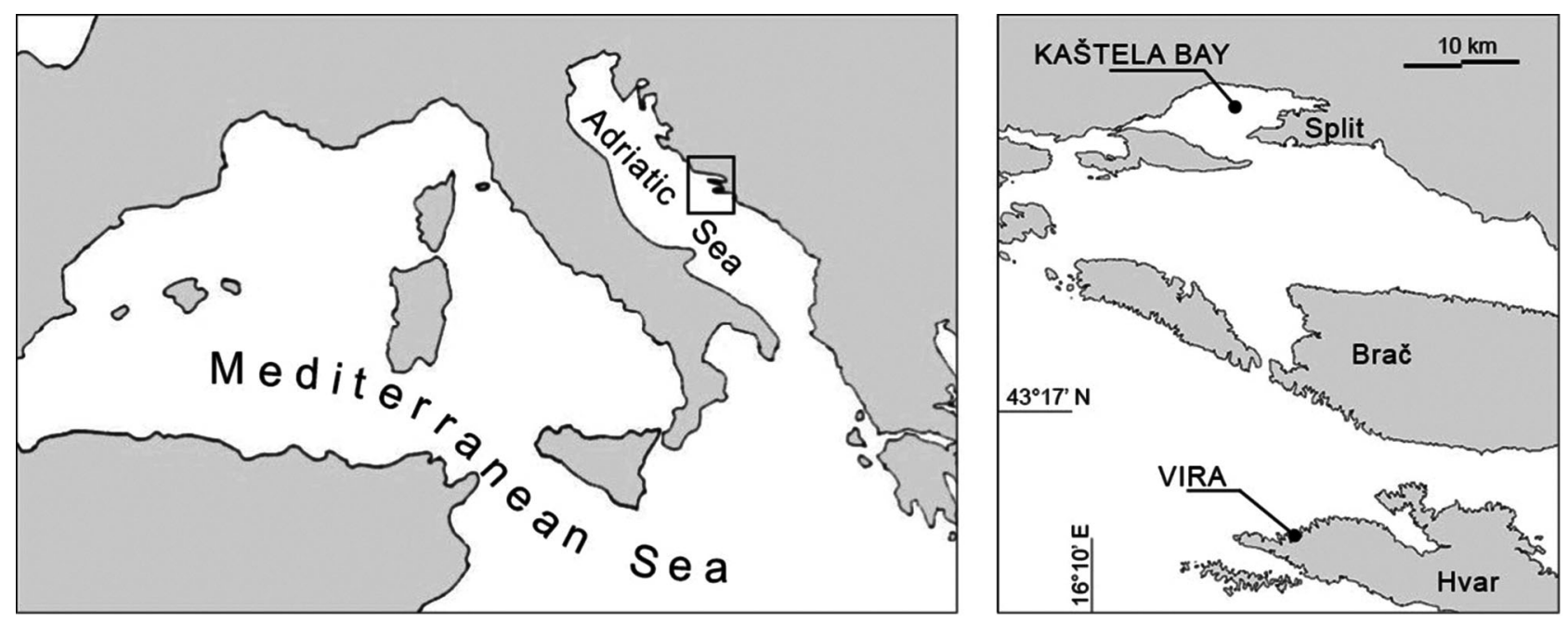

Fig. 1. Collection sites of Asparagopsis sp. infected with the pathogen Olpidiopsis feldmanni. Collections of infected material were successful at these sites in December 2012/2013 and March 2014

Table 2. Average surface seawater temperature $(T)$ and salinity in Kaštela Bay during the period during which infected Asparagopsis sp. tetrasporophytes were observed

\begin{tabular}{|ccc|}
\hline Date & $T\left({ }^{\circ} \mathrm{C}\right)$ & Salinity (PSU) \\
\hline 2012 & & \\
Nov & 17 & 36.5 \\
Dec & 14 & 36.5 \\
2013 & & \\
Jan & 12 & 36.2 \\
Feb & 11.5 & 36.3 \\
Mar & 12.5 & 35.5 \\
\hline
\end{tabular}

manent mounts were viewed in Aberdeen (UK) using a ZEISS Axio imager D2 ${ }^{\mathrm{TM}}$ inverted microscope (magnification 4-40×) and were imaged using a ZEISS Axiocam MRCTM. Images were acquired and processed using the ZEISS Zen ${ }^{\mathrm{TM}}$ image processing software. For TEM, infected algal thalli were collected from the field and shipped in seawater from Split to Athens. The fresh material was subsequently fixed, processed and imaged as previously reported (Sekimoto et al. 2008a), with slight modifications to the initial fixative buffer; in the present study, thalli were fixed with $2.5 \%$ glutaraldehyde in $0.1 \mathrm{M}$ sodium cacodylate buffer containing 0.25 M sucrose. Examination of the sections was performed with a Philips 300 transmission electron microscope.

\section{Molecular methods}

DNA extraction was performed on environmental samples (i.e. placed in CTAB at the time of collection) where no other eukaryotes (i.e. diatoms) or parallel infection was detected in the permanent mounts prepared, as detailed by Gachon et al. (2009). DNA extracts were then quantified and checked for quality using a spectrophotometer (260/280 nm) before being diluted to suitable concentrations for the purposes of PCR (10-50 ng $\mathrm{ul}^{-1}$ ).

Using the oomycete sequences available in the public domain, oomycete-specific primers were designed to amplify the small subunit (SSU) rRNA marker, SFP312F (5'-ATG AAT CAA TTG AGT TTC TG-3') and SFP1629R (5'-GAC GTA ATC AAT GCA AGC-3') using $4.0 \mathrm{mM} \mathrm{MgCl}_{2}$ and a PCR cycle of $95^{\circ} \mathrm{C}$ for $5 \mathrm{~min} ; 35$ cycles of $95^{\circ} \mathrm{C}$ for $30 \mathrm{~s}, 56^{\circ} \mathrm{C}$ for $30 \mathrm{~s}$ and $72^{\circ} \mathrm{C}$ for $60 \mathrm{~s}$; and $72^{\circ} \mathrm{C}$ for $5 \mathrm{~min}$. The cytochrome oxidase subunit II (COII) marker was amplified using the primers defined by Hudspeth et al. (2000) using $3.5 \mathrm{mM} \mathrm{MgCl}_{2}$ and a PCR cycle of $95^{\circ} \mathrm{C}$ for $5 \mathrm{~min} ; 35$ cycles of $95^{\circ} \mathrm{C}$ for $30 \mathrm{~s}, 50^{\circ} \mathrm{C}$ for $30 \mathrm{~s}$ and $72^{\circ} \mathrm{C}$ for $45 \mathrm{~s}$; and $72^{\circ} \mathrm{C}$ for $5 \mathrm{~min}$. An aliquot of the PCR product was run on a $1 \% \mathrm{w} / \mathrm{v}$ agarose gel in $1 \times$ Tris-borate-EDTA (TBE) buffer, stained with Gel$\operatorname{Red}^{\mathrm{TM}}$ (Biotium) and viewed on a UV lightbox, prior to purification (ThermoScientific GeneJet ${ }^{\mathrm{TM}}$ nucleic acid purification kit). The PCR products were sequenced using the primers, used for initial amplification, by the Eurofins Value Read ${ }^{\mathrm{TM}}$ sequencing service. The COII and SSU rRNA sequences were deposited under accession numbers KM210528 and KM210530, respectively.

The ABI files returned were initially manually trimmed and inspected for erroneous base callings using BioEdit ${ }^{\mathrm{TM}}$ (Hall 1999), and a single consensus 
sequence was created for each marker. Blastn/x was used to assign preliminary identities to sequences, and alignments of oomycetes were downloaded from NCBI. Alignments were tested with the maximum likelihood (ML) algorithm using RAxML 8.1.11 (Stamatakis 2006) through the CIPRES gateway (www. phylo.org/sub_sections/portal/), using a BLOSUM62 substitution matrix for the COII amino acid alignment and a GTRCAT model for the SSU rRNA, recording branch length and allowing bootstrapping to stop automatically. Hyphochytrids were used as outgroups in every test. To ensure consistent topology, neighbourjoining (NJ) tests were also performed on the same alignments with MEGA6.0 (Tamura et al. 2013) using a p-distance (COII) and Tajima-Nei (SSU rRNA) model, with gaps treated as partial deletions above a $95 \%$ cut-off and 1000-bootstrap test of phylogeny. Alignments and the NCBI accessions of sequences used are available in the Supplement at www.intres.com/articles/suppl/d117p045_supp.pdf.

\section{RESULTS}

\section{Field and microscopic observations}

Asparagopsis sp. tetrasporophytes infected by Olpidiopsis feldmanni were present in Vira (December 2012) and Kaštela Bay (December to January of 2012/13 and 2013/14 and March 2014; Fig. 1). They were found epiphytic on Stypocaulon scoparium (Linnaeus) Kützing, 1843, and Cladophora prolifera (Roth) Kützing, 1843, or epilithic between 0.5 and 1.5 m depth. The occurrence of Asparagopsis sp. tetrasporophytes in this geographic region is maximal between October and February, commonly between 0.5 and $3 \mathrm{~m}$ depth, and is observed to naturally decline in March. By analysing the IOF photo-microscopy database, outbreaks of this pathogen were also found to be present in Kaštela Bay in November 2006.

Light micrographs of fresh material and permanent mounts demonstrated a specific discolouration and enlargement of various cells of the Asparagopsis filament, inside which holocarpic parasitic thalli develop (Fig. 2A). After some time, under aquarium conditions, these thalli could be seen to have emptied and diatoms became established upon the alga (Fig. 2B). Most of the infection occurred in younger parts of the Asparagopsis filaments, while almost none occurred in the oldest cells. Infection of cells inside filaments results in formation of oblong parasitic sporangia (Fig. 2C). Pearson's correlation determined that their dimensions corresponded to enlarged dimensions of neighbouring parallel cells and by extension, the infected Asparagopsis cell, being 39 to $76 \mu \mathrm{m}$ in length ( $\mathrm{R}=0.8173$; see the Supplement). Infection of apical cells results in the formation of spherical parasitic sporangia which are within the range of 27 to $63 \mu \mathrm{m}$ in diameter (Fig. 2D,I-K and see Fig. 3A; additional measurement data are available in the Supplement), although in rare instances, non-spherical sporangia could be seen (Fig. 2E). We detected a significant difference between the length of the oblong sporangia and the diameter of spherical sporangia (t-test, $\mathrm{p}<$ 0.01; see the Supplement) as previously reported (Aleem 1952, 1953, Sparrow 1960). Occasionally exit tubes were visible on sporangia, both full and empty (Fig. 2F,G); typically, a single exit tube was visible, but in some instances multiple (up to 3) tubes could be seen (Fig. 2H). Discharge tubes are straight and measure approximately 11 to $55 \mu \mathrm{m}$ long and 3.6 to $6.5 \mu \mathrm{m}$ wide. The cleavage of zoospores appears before the release, and it appears that single spores can be seen as cleaved in some permanent mounts, though never in enough detail to see flagella (Fig. 2J).

\section{TEM}

A pathogenic walled thallus (Fig. 3A,B) at a stage comparable to the one shown by bright field imaging (Fig. 3A, inset), was located using TEM, allowing ultrastructural investigation of the pathogen. The walled thallus has an apical position and is illustrated here in 2 different TEM sections, both with and without a central vacuole of lipid texture (Fig. 3A-C). Numerous parasite nuclei with associated vesicles and mitochondria appear to dominate the thallus at this stage (Fig. 3A-C). The absence of membranes around the nuclei of the coenocytic cytoplasm (Fig. 3D) and of formed exit tubes implies that this phase corresponds to a pre-cleavage stage. Higher magnifications identified further ultrastructural features, such as tubular vesicles containing mastigonemes surrounded by mitochondria (Fig. 3E) and suspected kinetosomes (Fig. 3F). It should be noted that the material is taken directly from the field, a fact not allowing repetition of sampling and improvement of the fixation. Additionally a thick, electronlucent cell wall ( 1.3 $\mu \mathrm{m}$; arrowed line in Fig. 3G) surrounding the pathogen separates the contents of the parasitic thallus from the host cytoplasm and organelles which appear pushed aside (Fig. 3B,G), with chloroplasts clearly visible at high magnifications (Fig. 3G). The host cell wall remains intact, encapsulating the parasite thallus (Fig. 3G). 

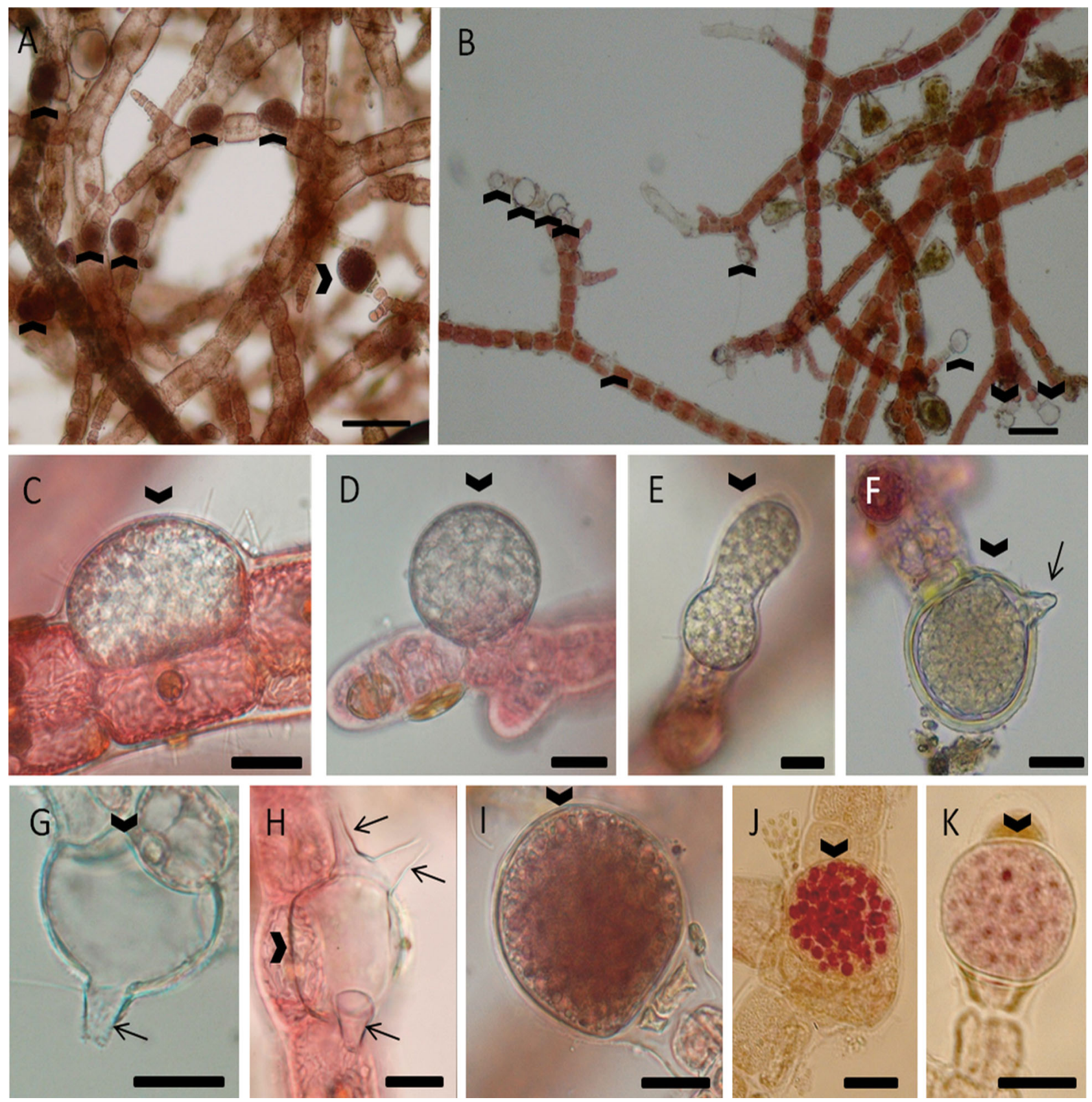

Fig. 2. Light micrographs of Olpidiopsis feldmanni infecting the tetrasporophytic stage of Asparagopsis sp., with specific focus on the sporangia. (A) Heavily infected material with sporangia and (B) late-stage infected material where the sporangia have been emptied, releasing infectious zoospores. The alga is vulnerable to being colonised by diatoms at this stage. (C-E) Individual sporangia, both (C) intercalated in an algal filament where the sporangium is forced into a bulging shape by the plant, and (D) infecting an apical cell where the oomycete has adopted the more common spherical sporangia, though in rare instances (E) alternative sporangium morphology is seen. (F-H) Typically 1, though (rarely) up to 3 exit tubes protrude from both forming and evacuated sporangia. (I-K) Permanently mounted preparations, where sporangia are dyed red by acetocarmine. (I) Large apical cell, swollen over $50 \mu \mathrm{m}$ in diameter. (J) Sporangium above the algal filament, suggesting that a new branch was forming facing upwards; individual zoospores can clearly be differentiated, suggesting a maturing sporangium. (K) Spherical cells were also formed in cells that were not apical, though still young. In all images, sporangia/empty sporangia are highlighted with thick arrowheads and exit tubes with arrows. Scale bars $=(A, B) 50 \mu m,(C-J) 20 \mu \mathrm{m}$ 


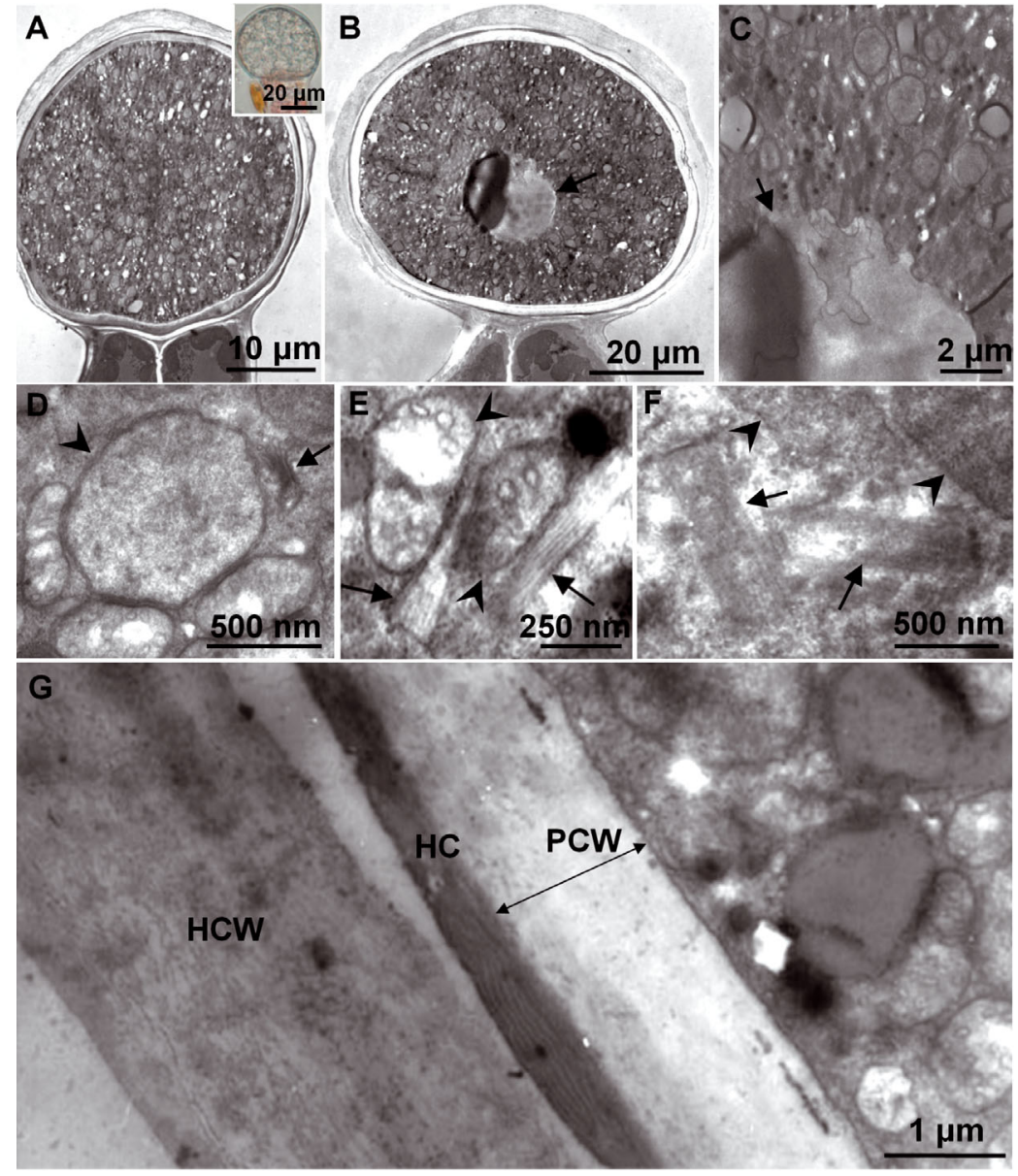

Fig. 3. Transmission electron microscopy images of the walled thallus of Olpidiopsis feldmanni. (A) Apical host cell, enlarged due to the presence of the O. feldmanni coenocytic walled thallus. Inset: Light micrograph of the parasite's walled thallus at a corresponding stage. (B) Deeper section of the same parasite's walled thallus reveals a central vacuole (arrowed), hypothesised to be involved in the cleavage process of the zoosporangium. (C) High magnification of the parasite's walled thallus demonstrates the nuclei and the vesicles bordering the central vacuole with content of lipid texture (arrowed). (D) Parasite nucleus (arrowhead) surrounded by a cluster of mitochondria and a dictyosome (arrow). (E) Parasite mitochondria (arrowheads) adjacent to rectangular cysts with mastigonemes (arrows). The tubular structure of mitochondrial cristae is visible. (F) Suspected kinetosomes (arrowed), with neighbouring mitochondria (arrowheads). (G) Adjacent host and parasite cell walls. The parasite cell wall (PCW) appears to be larger than previously reported in other oomycetes. The host cytoplasm (HC) and organelles appear pushed aside between the host cell wall (HCW) and PCW. Host chloroplasts are still visible

\section{Phylogenetic trees}

All successfully amplified fragments were taken from environmental samples where corresponding permanent mounts indicated a significant infection within the red alga. No signs of a parallel infection were ever noted, so we are confident that the se- quences obtained truly belong to the algal pathogen. The SSU rRNA fragment obtained (KM210530) when tested (Fig. 4) placed the Asparagopsis sp. pathogen alongside the oomycete Olpidiopsis bostrychiae (bootstrap support-ML: 99/100, NJ: 98/100) in a clade with $O$. porphyrae, $O$. pyropiae and 4 environmental sequences (Table 3; ML: 96/100, NJ: 61/100). Depending on the test of phylogeny, these environmental sequences could be seen to be closer to either $O$. bostrychiae and the Asparagopsis sp. pathogen (ML; Fig. 4A) or to O. por-

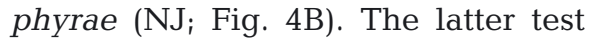
weakly associated $O$. pyropiae to $O$. bostrychiae and our newly obtained sequence, but with very poor support (36/100; Fig. 4B). Additional to this, the relationship between genera is slightly altered depending on the test used; ML supports that the Olpidiopsidales and Haliphthorales are both an equal distance from all other oomycetes (59/100; Fig. 4A), whereas the NJ test weakly supports the separation of this branch, placing the Olpidiopsidales closer to the non-basal oomycetes (50/100; Fig. 4B). No other branching deviations were noted between tests. Similarly, the COII fragment obtained (KM210528) when tested (Fig. 5) placed the Asparagopsis sp. pathogen with $O$. bostrychiae (100/100), although the association of $O$. porphyrae with this clade was very weak when assessed by ML $(<50)$ and is moved to associate within the Haliphthorales clade when tested by NJ. In addition, the close association of Halioticida sp. NJM_0034 (<50) with Olpidiopsidales shown by the COII marker is not reflected in the previous SSU rRNA topology, where this abalone pathogen is seen to branch towards the non-basal oomycetes a step above Olpidiopsis in agreement with a recent large subunit rRNA phylogeny study of this genus (Macey et al. 2011). High-order branches of the COII with weak support (i.e. <70) could be collapsed by the inclusion/exclusion of certain taxa, concurrent with previous studies (Sekimoto et al. 2009). 

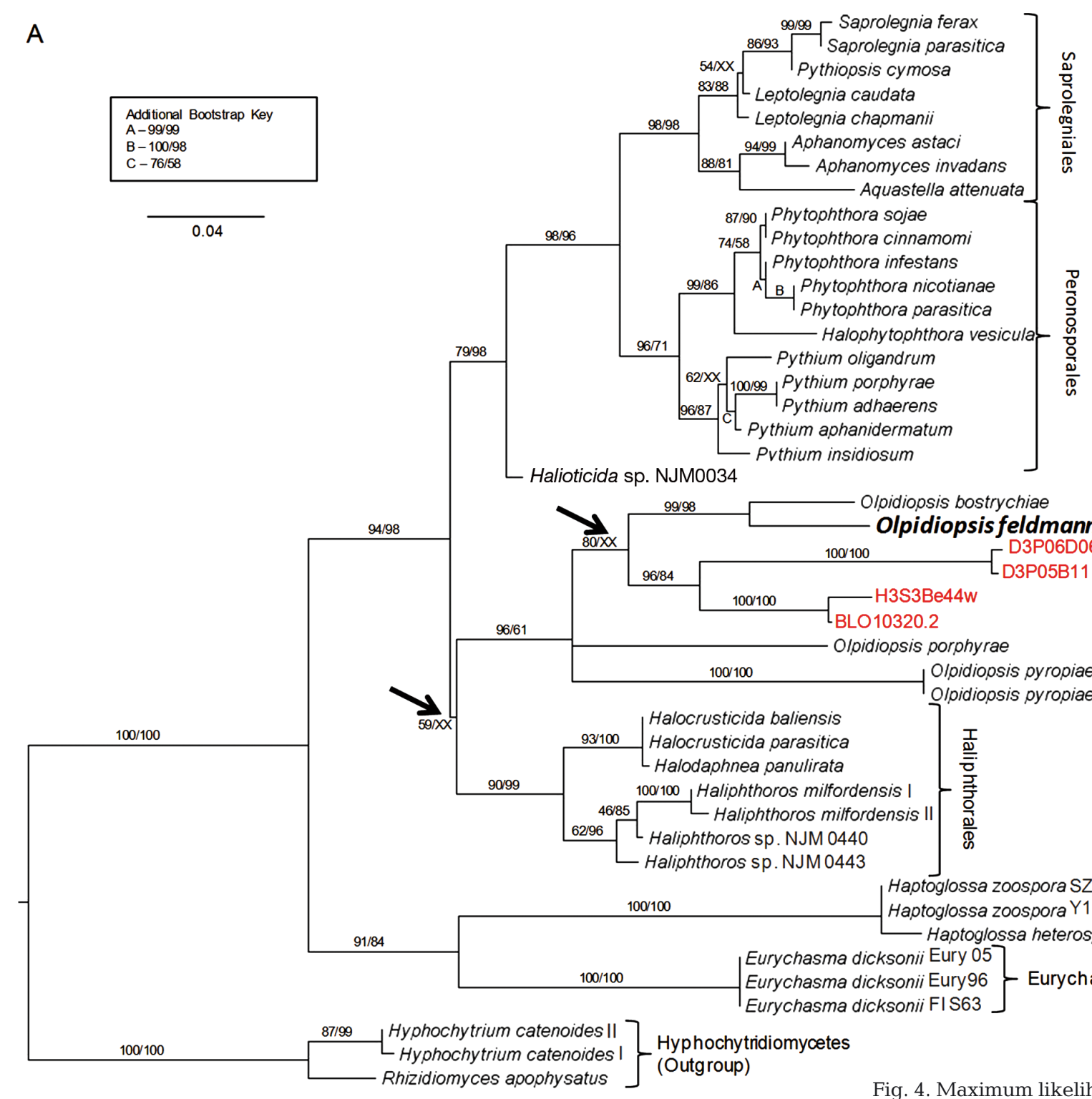

B
0.04

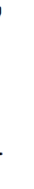


Table 3. Environmental samples which branch within the marine Olpidiopsis clade. GenBank accession numbers

\begin{tabular}{|lllll|}
\hline Tag identifier & Accession & Author & Water/country of discovery & Notes \\
\hline D3P05B11 & EF100276.1 & Stoeck et al. (2007) & Baffin Bay/Greenland & $\begin{array}{l}\text { Oxygen depleted intertidal marine } \\
\text { sediment, upper 2 cm }\end{array}$ \\
D3P06D06 & EF100297.1 & Stoeck et al. (2007) & Baffin Bay/Greenland & \\
BL010320.2 & AY381206.1 & Massana et al. (2004) & Mediterranean Sea/Spain & Coastal surface water \\
H3S3Be43I & JQ781890.1 & Lin et al. (2012) & Pacific Ocean/USA & Ocean waters \\
\hline
\end{tabular}

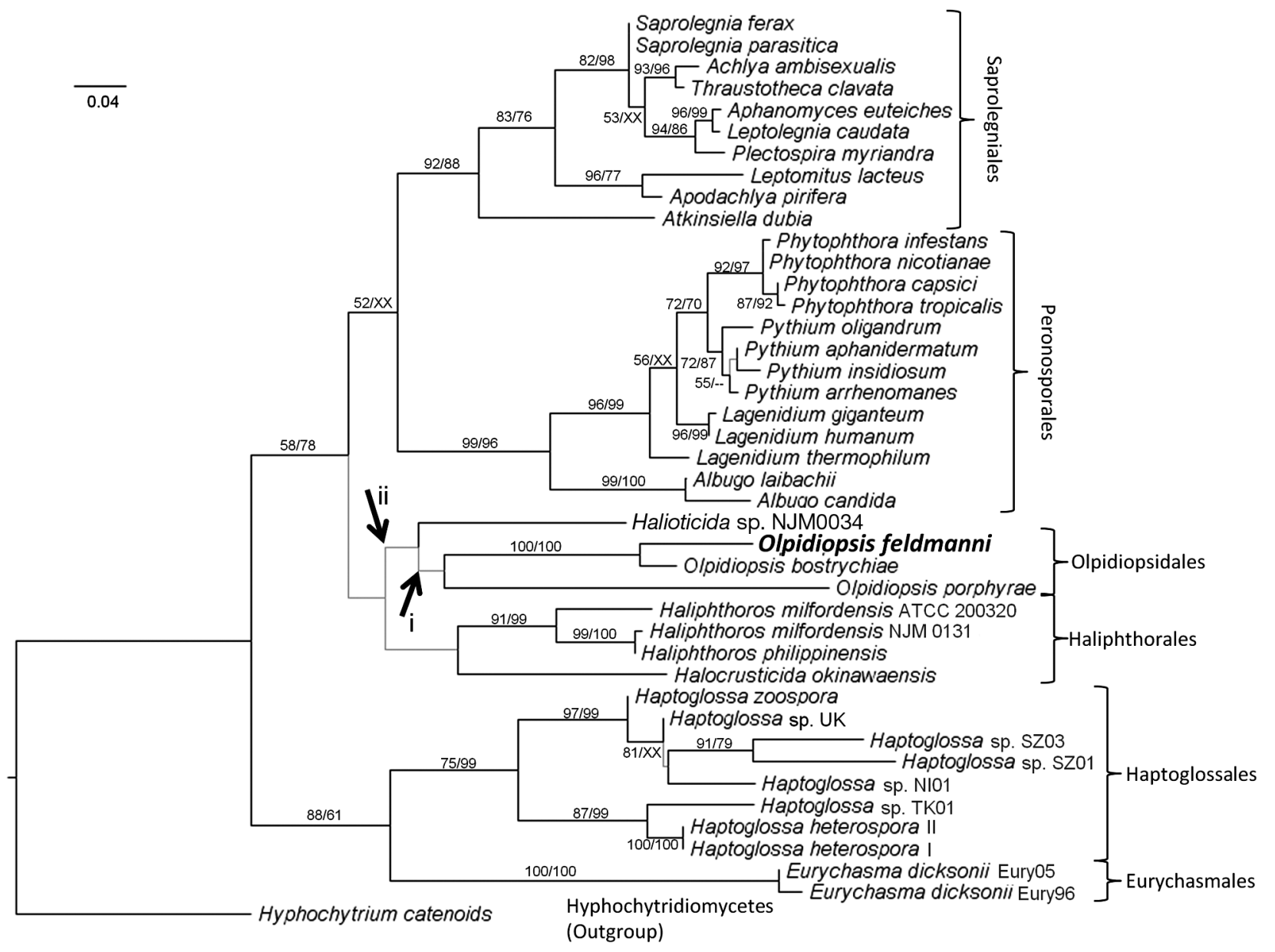

Fig. 5. Maximum likelihood (ML) tree based on the COII marker testing 42 sequences. Branches are labelled with percentage support from 1000 bootstrap tests of phylogeny from the ML test and a corresponding neighbour joining (NJ) test, if there was $>50 \%$ support at the node. Branches with $<50 \%$ support are grey, and 'XX' indicates that the node was not predicted in the NJ test. Arrowed nodes were not predicted by NJ, resulting in a significant tree rearrangement; data not shown. Alignment and accession numbers are provided in the Supplement

\section{DISCUSSION}

\section{Olpidiopsis feldmanni: identification and confirmation}

Light microscopic investigations of the pathogen found infecting the tetrasporophytic (Falkenbergia) stage of Asparagopsis sp. are congruent to the descriptions of Olpidiopsis feldmanni (Sparrow 1960) originally described from the Mediterranean Sea (French coast; Aleem 1952) and Baltic Sea (Sweden; Aleem 1953). Uniquely, a rare observation of a nonspherical sporangium in the apical host cell (Fig. 2E) and a significantly larger sporangial size in apical 
cells were recorded (average diameter of $40 \mu \mathrm{m}$, ranging from 27.33 to $62.54 \mu \mathrm{m}$ [see the Supplement]; previously 15-30 $\mathrm{mm}_{\text {; }}$ Sparrow 1960). Comparing the size of an infected cell with that of an adjacent, parallel cell provided a strong correlation, suggesting that the host may limit the expansion of the pathogenic thallus, as indicated by the shape adopted in older cells of the host alga. Comparatively, spherically shaped thalli, i.e. the natural shape of an Olpidiopsis thallus (West et al. 2006), can be seen in younger apical cells (Fig. 2). Indications of host hyperplasia are noted (Fig. 2), where the host cell appears to have become enlarged due to reproduction of the pathogen, similar to instances seen in other holocarpic oomycete pathogens, such as Eurychasma dicksonii (Sekimoto et al. 2008a) and $O$. antithamnionis (Whittick \& South 1972).

Key ultrastructural similarities between this pathogen and other oomycetes (i.e. Olpidiopsis sp. and Eurychasma sp.) indicate that this is a correct diagnosis with the pathogen presenting a coenocytic walled thallus, containing multiple nuclei and mitochondria. A similar organization is presented by the protoplast of other oomycetes, such as in the walled vegetative thalli of $O$. porphyrae and O. bostrychiae (Sekimoto et al. 2008b, 2009) and in the immature zoosporangium of E. dicksonii at a pre-cleavage stage (Sekimoto et al. 2008a). Additionally, a large central vacuole can be observed in this thallus, similar to that seen in $O$. bostrychiae but absent in $O$. porphyrae and $O$. pyropiae which present multiple vacuoles at this stage (Sekimoto et al. 2008b, 2009, Klochkova et al. 2012). Interestingly, a single large vacuole is reported from the dormant cysts of $O$. pyropiae (Klochkova et al. 2015). It is not reported whether presenting multiple vacuoles occurs after differing maturation processes. O. pyropiae has been recorded as regularly having smaller developing thalli with vacuoles, which may fuse to larger vacuolated thalli (Klochkova et al. 2015). It seems possible that this fusion may result in multiple, smaller vacuoles being present in a thallus, although the original study did not report this. This fusion, however, was indicated as a rationale for an unusual number of zoospores being detected in mature thalli (i.e. not to the power of 2; Klochkova et al. 2015).

A final unique ultrastructural observation from our O. feldmanni material is the enlarged cell wall presented by this pathogen (Fig. 3G), which has approximately 6 times the thickness of the cell wall of $O$. porphyrae, $O$. bostrychiae, O. pyropiae and E. dicksonii ( 200-400 nm) at corresponding phases (Sekimoto et al. 2008b, 2009, Klochkova et al. 2015,
Tsirigoti et al. 2015). Given that the latter species are imaged from established host-pathogen cultures, it may be that an environmental agent which is not present in the culture is responsible for this increase in size.

This diagnosis correlates with the phylogenetic analysis, where both markers surveyed were able to consistently associate the Asparagopsis sp. pathogen with $O$. bostrychiae (Figs. $4 \& 5$ ). The relative ease with which the sequences were obtained with primers shown to amplify multiple oomycete genera (Hudspeth et al. 2000) suggests that no other oomycetes were present in our samples and is supported by detailed examination of permanent mounts.

In summary, the SSU rRNA (Fig. 4) can be seen as being the key marker for the basal oomycetes. The relatively highly conserved nature of the marker appears well suited to resolving the branching order of the few sampled basal oomycete species and consistently supported the placement of the marine Olpidiopsis species into a single clade. Four environmental samples were also found to clade within this genus, which could be seen as additional marine Olpidiopsidales sequences surveyed directly from the environment (Table 3) but not morphologically investigated. Depending on the test of phylogeny used, the nearest Olpidiopsis sp. relative to these 4 environmental sequences would change (Fig. 4), although the support of the NJ topology is significantly reduced relative to the ML topology. An additional topological difference noted between these tests is the relationship between the orders Olpidiopsidales and Haliphthorales. These orders were weakly grouped together when tested by ML (Fig. 4A), i.e. branching the same distance from every other oomycete, but when tested by NJ, they were weakly supported as being differentiated (Fig. 4B) with the Olpidiopsidales branching towards the non-basal oomycetes. This uncertainty in the placement of the basal oomycete orders suggests that there may be a large amount of genetic diversity between these orders, yet to be surveyed. Additionally, the long branch distances between the Olpidiopsis species (Sekimoto et al. 2009, Klochkova et al. 2015) supports a large genetic distance between the currently surveyed Olpidiopsis species, and it is possible that there will be a large diversity of intermediate species, as yet undetected.

This weak association is further highlighted by the COII marker which poorly supports the clading of the 3 Olpidiopsis species surveyed at this marker (Fig. 5), with no corresponding sequences for $O$. pyropiae being available at this time. In agreement with previ- 
ous findings (Sekimoto et al. 2009), we also noted that altering the taxa surveyed could significantly affect the topology, in particular the placement of O. porphyrae and Halioticida sp.

While these analyses have shown that there is a close association morphologically, ultra-structurally and genetically between $O$. feldmanni and $O$. bostrychiae, these are still regarded as 2 distinct species. While it was not possible to evaluate the host range of $O$. feldmanni, due to the inability to bring this organism into culture, a previous host range analysis has been performed on $O$. bostrychiae, which was unable to successfully infect Asparagopsis sp. in vitro (West et al. 2006, Sekimoto et al. 2009). As a host is required to fulfil the life cycle (and the reported sexual cycle; Martin \& Miller 1986a) of all Olpidiopsis sp., the inability to infect the same host species can be regarded as an adequate species barrier between these 2 organisms at present. It should be noted here that sex in marine Olpidiopsis species has not been observed to date; indeed, recent TEM investigations of fusing $O$. pyropiae thalli failed to identify the fusing of any nuclei (Klochkova et al. 2015).

This new record from the Adriatic constitutes the first published finding of $O$. feldmanni in over $60 \mathrm{yr}$ and provides the first set of molecular markers for this species. Prior to this, O. feldmanni has only been reported from Asparagopsis sp. and Bonnemaisonia hamifera (Agardh) Silva, 1957, in the Mediterranean and Baltic Seas (Aleem 1952, 1953, Sparrow 1960). It is unclear, given that Asparagopsis spp. are considered invasive in the Mediterranean Sea (Garzoli et al. 2014), what the geographic origins of O. feldmanni are. Further studies to establish the host range are necessary to determine whether any native Mediterranean algal species are susceptible. Given the previous geographic records, it is not unimaginable that the parasite may be present in most other marine regions within western Europe where the host is present. Indeed, the regular occurrence of O. feldmanni infecting Asparagopsis sp. in the autumn on the south and west coast of the British Isles has been suggested, but no evidence was reported to substantiate this claim (Dixon \& Irvine 1977). As the pathogen was found year to year during this study and was also detected in historical images, it can be supposed that this pathogen is an established member of the community and regular epidemics can be expected during the annual occurrence of the tetrasporophytic stage of Asparagopsis sp. The orthology of this species is retained as $O$. feldmanni in concurrence with the original description of this species (Aleem 1952), as with pre- vious studies (West et al. 2006, Sekimoto et al. 2008b, 2009, Klochkova et al. 2015). The recently suggested reclassification of the Olpidiopsis species into differing genera based on host range (Dick 2001) is regarded as premature due to a lack of phylogenetic knowledge.

\section{Olpidiopsis sp.: a morphological overview}

The key differences between the marine and freshwater Olpidiopsis species, studied through electron microscopy, are summarised in Table 4. Observations by light microscopy highlight the different flagellation pattern presented by the marine species. O. bostrychiae presents laterally biflagellate zoospores (West et al. 2006, Sekimoto et al. 2009), which appears to be a common feature of most marine Olpidiopsis species (Whittick \& South 1972), while $O$. porphyrae and $O$. pyropiae present sub-apically biflagellate zoospores (Sekimoto et al. 2008b). The holotype species $O$. saprolegniae also presents subapically biflagellate zoospores (Bortnick et al. 1985).

In addition to this, TEM of developing walled thalli reveals a single central vacuole present in the maturing thallus of $O$. feldmanni and $O$. bostrychiae (Sekimoto et al. 2009). In comparison, $O$. porphyrae, $O$. pyropiae and the freshwater species $O$. varians present multiple vacuoles of a similar density (Karling 1949, Martin \& Miller 1986b, Sekimoto et al. 2008b), while $O$. pyropiae may present one or more vacuoles, as identified by light microscopy (Klochkova et al. 2012). Previous observations suggest that these vacuoles may facilitate cleavage during zoosporogenesis of holocarpic stramenopiles (Karling 1942, 1943). Subsequent ultrastructural studies from biflagellate Petersenia palmariae, a pathogen of Palmaria mollis, supported this (Pueschel \& van der Meer 1985), while expulsion vacuoles have been described from germinating cysts of the biflagellate Ectrogella perforans (Kumar 1980). Recently, the organization of the cytoskeleton during the process of infection and sporangium development was studied in a brown algal host cell and the parasite E. dicksonii. It is assumed that the cleavage procedure is directed by a modified system of microtubules and a central vacuole that appears during this phase (Tsirigoti et al. 2014). These 3 features would lend weight to a hypothesis that freshwater Olpidiopsis species are more closely related to O. porphyrae and O. pyropiae than the 2 other marine species genetically surveyed. With this hypothesis in mind and the large genetic difference observed between marine Olpidiopsis species, it 


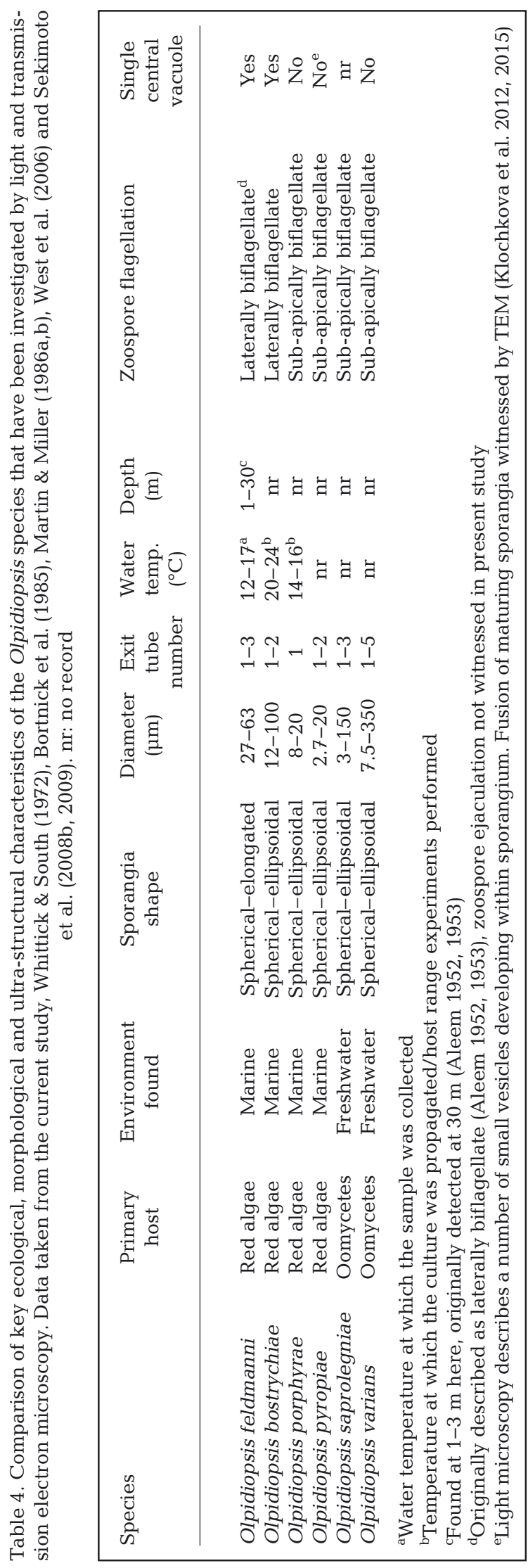

could be seen as justifiable to attempt to delineate these species into 2 separate genera. Yet as the species at present form a monophyletic clade, we believe that this would be a premature and potentially irrelevant nomenclature change. This rationale is supported by the ecology (i.e. marine) and host species (i.e. red algae) of the genetically surveyed marine Olpidiopsis species (Table 1), which should still be regarded as significant. It may be the case that freshwater Olpidiopsis, when genetically surveyed, will be further removed from all marine Olpidiopsis species. Unfortunately, with the limited molecular surveying of basal oomycetes, any tentative placement of these species based on morphological characteristics only should be viewed as highly speculative. Instead, resolving the phylogenetic position of freshwater Olpidiopsis species, through genetic screening, should be considered a key route to expand our knowledge of this highly diverse genus.

\section{CONCLUSION}

The present study identified Olpidiopsis feldmanni in nature, obtaining live environmental isolates, enabling investigation of this pathogen through molecular phylogenetics as well as light and electron microscopy, with significant evidence showing this pathogen to be genetically and morphologically closer to O. bostrychiae than to O. porphyrae or O. pyropiae. We note that in order to ensure the assigned sequences are correct, meticulous observation of the algae and associated material was necessary to ensure no second oomycete species was present in the DNA extraction. Additionally, as only 1 sequence was obtained with oomycete-wide directed COII primers, we are confident that only 1 oomycete species was present in our samples. This type of study is effective when expanding the knowledge of the existing catalogue of oomycetes (Sparrow 1960) for which reference molecular data exist. When molecularly surveying a new genus or a distant phylogenetic branch, where no reference data are available, then either pure cultures or fluorescent in situ hybridisation protocols (Langer-Safer et al. 1982) must be established.

Acknowledgements. We are grateful to the Total Foundation (Paris) for its funding support to this study, to the UK Natural Environment Research Council (NERC) for a doctoral fellowship to K.F. and to the MASTS pooling initiative (Marine Alliance for Science and Technology for Scotland, funded by the Scottish Funding Council and contributing institutions; grant reference HR09011). 


\section{LITERATURE CITED}

Aleem AA (1952) Olpidiopsis feldmanni sp. nov., champignon marin parasite d'algues de la famille des Bonnemaisoniacées. C R Acad Sci 235:1250-1252

Aleem AA (1953) Marine fungi from the west-coast of Sweden. Ark Bot 2:1-33

Andrews JH (1976) The pathology of marine algae. Biol Rev Camb Philos Soc 51:211-252

> Bortnick RN, Powell MJ, Bangert TN (1985) Zoospore fine structure of the parasite Olpidiopsis saprolegniae variety saprolegniae (Oomycetes, Lagenidiales). Mycologia 77: 861-879

Dick MW (2001) Straminipilous fungi. Systematics of the Peronosporomycetes including accounts of the marine straminipilous protists, the Plamodiophorids and similar organisms. Kluwer Academic Publishers, Dordrecht

Dixon PS, Irvine LM (1977) Seaweeds of the British Isles, Vol 1. British Museum (Natural History), London

> Gachon CMM, Strittmatter M, Müller DG, Kleinteich J, Küpper FC (2009) Detection of differential host susceptibility to the marine oomycete pathogen Eurychasma dicksonii by real-time PCR: Not all algae are equal. Appl Environ Microbiol 75:322-328

Gachon CMM, Sime-Ngando T, Strittmatter M, Chambouvet A, Kim GH (2010) Algal diseases: spotlight on a black box. Trends Plant Sci 15:633-640

Garzoli L, Gnavi G, Varese GC, Picco AM (2014) Mycobiota associated with the rhodophyte alien species Asparagopsis taxiformis (Delile) Trevisan de Saint-Léon in the Mediterranean Sea. Mar Ecol, doi:10.1111/maec.12189

Hall TA (1999) BioEdit: a user-friendly biological sequence alignment editor and analysis program for Windows 95/98/NT. Proc Nucleic Acids Symp Ser 41:95-98

$>$ Hudspeth DSS, Nadler SA, Hudspeth MES (2000) A COX2 molecular phylogeny of the Peronosporomycetes. Mycologia 92:674-684

Jokl M (1916) Eine neue Meereschytridinee: Pleotrachelus ectocarpii nov. spec. Österr Bot Z 66:267-272

Karling JS (1942) The simple holocarpic biflagellate Phycomycetes, Vol 1. New York, NY

Karling JS (1943) The life history of Anisolpidium ectocarpii gen. nov. et sp. nov., and a synopsis and classification of other fungi with anteriorly uniflagellate zoospores. Am J Bot 30:637-648

Karling JS (1949) A new Olpidiopsis parasite of Karlingia rosea from Maryland. Mycologia 41:270-276

> Klochkova T, Shim J, Hwang M, Kim G (2012) Host-parasite interactions and host species susceptibility of the marine oomycete parasite, Olpidiopsis sp., from Korea that infects red algae. J Appl Phycol 24:135-144

Klochkova T, Shin Y, Moon KH, Motomura T, Kim G (2015) New species of unicellular obligate parasite, Olpidiopsis pyropiae sp. nov., that plagues Pyropia sea farms in Korea. J Appl Phycol 27:1-11

Kumar CR (1980) An ultrastructural study of the marine diatom Licmophora hyalina and its parasite Ectrogella perforans. II. Development of the fungus in its host. Can J Bot 58:2557-2574

Küpper FC, Müller DG (1999) Massive occurrence of the heterokont and fungal parasites Anisolpidium, Eurychasma and Chytridium in Pylaiella littoralis (Ectocarpales, Phaeophyceae). Nova Hedwigia 69:381-389

Küpper FC, Maier I, Müller DG, Loiseaux-de Goer S, Guillou L (2006) Phylogenetic affinities of two eukaryotic pathogens of marine macroalgae, Eurychasma dicksonii (Wright) Magnus and Chytridium polysiphoniae Cohn. Cryptogam Algol 27:165-184

> Langer-Safer PR, Levine M, Ward DC (1982) Immunological method for mapping genes on Drosophila polytene chromosomes. Proc Natl Acad Sci USA 79:4381-4385

> Lin YC, Campbell T, Chung CC, Gong GC, Chiang KP, Worden AZ (2012) Distribution patterns and phylogeny of marine stramenopiles in the North Pacific Ocean. Appl Environ Microbiol 78:3387-3399

Macey B, Christison K, Mouton A (2011) Halioticida noduliformans isolated from cultured abalone (Haliotis midae) in South Africa. Aquaculture 315:187-195

Martin RW Jr, Miller CE (1986a) Ultrastructure of sexual reproduction in Olpidiopsis varians. Mycologia 78: 359-370

> Martin RW Jr, Miller CE (1986b) Ultrastructure of zoosporogenesis in the endoparasite Olpidiopsis varians. Mycologia 78:230-241

> Massana R, Castresana J, Balagué V, Guillou L and others (2004) Phylogenetic and ecological analysis of novel marine stramenopiles. Appl Environ Microbiol 70:3528-3534

> Phillips N, Smith CM, Morden CW (2001) An effective DNA extraction protocol for brown algae. Phycological Res 49: 97-102

Pueschel CM, van der Meer JP (1985) Ultrastructure of the fungus Petersenia palmariae (Oomycetes) parasitic on the alga Palmaria mollis (Rhodophyceae). Can J Bot 63: 409-418

Sekimoto S, Beakes GW, Gachon CM, Müller DG, Küpper FC, Honda D (2008a) The development, ultrastructural cytology, and molecular phylogeny of the basal oomycete Eurychasma dicksonii, infecting the filamentous phaeophyte algae Ectocarpus siliculosus and Pylaiella littoralis. Protist 159:299-318

> Sekimoto S, Yokoo K, Kawamura Y, Honda D (2008b) Taxonomy, molecular phylogeny, and ultrastructural morphology of Olpidiopsis porphyrae sp. nov. (Oomycetes, Straminipiles), a unicellular obligate endoparasite of Bangia and Porphyra spp. (Bangiales, Rhodophyta). Mycol Res 112:361-374

Sekimoto S, Klochkova TA, West JA, Beakes GW, Honda D (2009) Olpidiopsis bostrychiae sp. nov.: an endoparasitic oomycete that infects Bostrychia and other red algae (Rhodophyta). Phycologia 48:460-472

Sparrow FK (1960) Aquatic phycomycetes, 2nd edn. The University of Michigan Press, Ann Arbor, MI

Stamatakis A (2006) RAxML-VI-HPC: maximum likelihoodbased phylogenetic analyses with thousands of taxa and mixed models. Bioinformatics 22:2688-2690

- Stoeck T, Kasper J, Bunge J, Leslin C, Ilyin V, Epstein S (2007) Protistan diversity in the Arctic: a case of paleoclimate shaping modern biodiversity? PLoS ONE 2:e728

Strittmatter M, Gachon CMM, Müller DG, Kleinteich J and others (2013) Intracellular eukaryotic pathogens in brown macroalgae in the Eastern Mediterranean, including LSU rRNA data for the oomycete Eurychasma dicksonii. Dis Aquat Org 104:1-11

Tamura K, Stecher G, Peterson D, Filipski A, Kumar S (2013) MEGA6: Molecular Evolutionary Genetics Analysis version 6.0. Mol Biol Evol 30:2725-2729

Tsirigoti A, Küpper F, Gachon C, Katsaros C (2014b) Cytoskeleton organisation during the infection of three brown algal species, Ectocarpus siliculosus, Ectocarpus crouaniorum and Pylaiella littoralis, by the intracellular marine 
oomycete Eurychasma dicksonii. Plant Biol 16:272-281

Tsirigoti A, Beakes GW, Herve C, Gachon CM, Katsaros C (2015) Attachment, penetration and early host defense mechanisms during the infection of filamentous brown algae by Eurychasma dicksonii. Protoplasma 252: 845-856

West JA, Klochkova TA, Kim GH, Loiseaux-de Goër S (2006)

Editorial responsibility: David Bruno,

Aberdeen, UK
Olpidiopsis sp., an oomycete from Madagascar that infects Bostrychia and other red algae: host species susceptibility. Phycol Res 54:72-85

Whittick A, South GR (1972) Olpidiopsis antithamnionis n. sp. (Oomycetes, Olpidiopsidaceae), a parasite of Antithamnion floccosum (OF Müll.) Kleen from Newfoundland. Arch Mikrobiol 82:353-360

Submitted: July 27, 2015; Accepted: September 14, 2015 Proofs received from author(s): November 1, 2015 